\title{
Baruch A Levine: A Personal Reflection
}

\author{
William W. Hallo \\ Yale University
}

I first encountered Baruch Levine in April, 1962, at the meeting of the American Oriental Society in Cambridge, where he gave a paper entitled "A Ugaritic-Rabbinic Cultic Parallel." I still have my abstract of the paper, with the marginal notation ("Brother of Little Joe L."). The late Joseph Levine was well known to me at Hebrew Union College in Cincinnati, where I was teaching at the time. Baruch's paper was based on the dissertation that he was then completing at Brandeis under Cyrus Gordon. It ran into the kind of crossfire reserved for "maiden-speeches" at the AOS by some of its older members including, in this case, the late Moshe Held. But Baruch, as was far less usual in these situations, held his ground. I was impressed and invited him to New Haven, where I was ready to take up duties in the fall. He was eager to continue publishing, his first article, "The Netinim," having appeared in the Journal of Biblical Literature in May, I963. I encouraged him to publish in the Journal of Cuneiform Studies, where his "Ugaritic Descriptive Rituals" appeared in December of the same year.

The title reflected our discussions of what I considered "archival" texts, abundant in Mesopotamia but rare at Ugarit. They had been the subject of his thesis, and they contained cultic information often overlooked by historians of religion. Thus began a lengthy and fruitful collaboration between us. It involved among other projects his "Descriptive Tabernacle Texts of the Pentateuch," which he published in the Journal of the American Oriental Society in 1965, while I was Associate Editor. Here he extended the concept of archival texts, or at least archival prototypes, to the Bible, a notion that I have gratefully exploited every since. He in turn made good use there of my concept of the two-dimensional account. (I remember having occasion to correct the arithmetic of one of his charts.) By $\mathrm{I}_{967}$, we were combining forces to apply all of these insights to two large Old Babylonian texts, which we edited together in the Hebrew Union College Annual under the title of "Offerings to the Temple Gates at Ur." The fold-out charts that accompa- 
nied this article must have taxed the ingenuity of the printer, not to mention the budget of the Annual.

The collaboration continued with Baruch's undertaking to edit for me the volume of neo-Sumerian texts left unfinished by their owner and copyist, Carl H. Lager. Although he eventually had to abandon the effort under the pressure of other commitments, his notes proved helpful to D. C. Snell in the final preparation of the material, which appeared as volume 18 of Yale Oriental Series in I99I. As recently as I995, he flattered me by asking for my critique of his essay on "The Balaam Inscriptions from Deir 'Alla" for his forthcoming commentary, Numbers 2 I -36 .

Besides these professional contacts, I have enjoyed a life-long friendship with Baruch and Corinne, cemented by their admiration for my late wife. I have fond memories of gourmet meals served by Baruch in New York, Jerusalem, and Lakeridge (Connecticut), and in the last location am happy to have become his neighbor. He is one of those rare scholars who, for all their academic attainments, retain their good humor, their love of life, and their capacity for the human touch. It can truly be said of him, as it was said of Israel to Balaam, "Surely he is blessed!" 
This page intentionally left blank. 